Article

\title{
Organochlorine Pesticides in Sediment of Zhang River Estuary Mangrove National Natural Reserve: The Implication of Its Source Change in China's Mangroves
}

\author{
Kai Chen ${ }^{1,2,3}$, Minggang Cai ${ }^{1,2,3,4, * \mathbb{D}}$, Yun Wang ${ }^{3}$, Bin Chen ${ }^{1}$, Xiaomeng Li ${ }^{3}$, Canrong Qiu ${ }^{3}$, \\ Shuiying Huang ${ }^{2}$, Jionghui Sun ${ }^{3}$, Xiaoyan Liu ${ }^{3}$, Bihua Qian ${ }^{3}$ and Hongwei Ke ${ }^{3}$ \\ 1 Coastal and Ocean Management Institute, Xiamen University, Xiamen 361102, China; \\ kchen@xmu.edu.cn (K.C.); 30420160154140@stu.xmu.edu.cn (B.C.) \\ 2 Fujian Provincial Key Laboratory for Coastal Ecology and Environmental Studies, Xiamen University, \\ Xiamen 361102, China; syhuang@xmu.edu.cn \\ 3 College of Ocean and Earth Science, Xiamen University, Xiamen 361102, China; \\ wangyun.ripp@sinopec.com (Y.W.); molly.lee@etraveligroup.com (X.L.); c.qiu@hzdr.de (C.Q.); \\ sunjionghui@163.com (J.S.); roseruse_lxy@126.com (X.L.); qbh40@126.com (B.Q.); \\ Hongwei_KE@xmu.edu.cn (H.K.) \\ 4 State Key Laboratory of Marine Environmental Science, Xiamen University, Xiamen 361102, China \\ * Correspondence: mgcai@xmu.edu.cn
}

Received: 22 February 2020; Accepted: 7 April 2020; Published: 9 April 2020

\begin{abstract}
Seventeen organochlorine pesticides (OCPs) were examined in surface sediments from Zhang River Estuary Mangrove National Natural Reserve, which is situated in the Fujian province in southeast China. The range of $\sum O C P$ s concentration was $0.29-25.41 \mathrm{ng} / \mathrm{g}$ dry weight (average $4.53 \mathrm{ng} / \mathrm{g}$ ), $\sum$ HCHs was $0.008-0.906 \mathrm{ng} / \mathrm{g}$ dry weight (average $0.240 \mathrm{ng} / \mathrm{g}$ ), and $\sum$ DDTs was ND-4.743 (average $0.664 \mathrm{ng} / \mathrm{g}$ ). The concentrations of the $\mathrm{HCH}$ isomers were observed in the following decreasing order: $\alpha-\mathrm{HCH}>\beta-\mathrm{HCH}>\delta-\mathrm{HCH}>\gamma-\mathrm{HCH}$, and that of the DDT isomers were as in the following order: $p, p^{\prime}$-DDT $>p, p^{\prime}$-DDE $>p, p^{\prime}$-DDD. According to the analysis of the isomer ratios, $\gamma-\mathrm{HCH}$ (lindane) and endosulfan were rarely used recently around this mangrove forest. Instead, the ratios of (DDD+DDE)/DDT showed that DDTs were still illegally used. Compared with other mangroves in China, the residue level and ecological risk of the OCPs in surface sediment from ZREMNNR are both at a low level. Based on stepwise regression analysis, current fruit planting, as well as mariculture in developed areas and vegetable planting in developing areas, had a positive relation with DDT residues in mangrove sediment in China. Oppositely, $\mathrm{HCH}$ residues in mangrove sediment were derived from historical consumption, and generally the higher levels occurred in the developed areas. Through this study, we help to close the knowledge gap of OCPs in China's mangroves and provide a possible management implication for sustainable development in the future.
\end{abstract}

Keywords: OCPs; sediments; mangrove; Zhang River Estuary; human activity

\section{Introduction}

Mangroves are characteristic plants growing in the tropical and subtropical intertidal zones around the world. Mangroves provide many ecological services, such as flood protection, biological habitat, carbon fixation, and water purification [1,2]. It is commonly known that mangroves have become one of the most threatened and vulnerable ecosystems with increasing ecological pressure from intensive human activities. Especially, mangroves forests act as an important buffer that absorb 
anthropogenic chemicals because of a high primary productivity, abundant organic matter scrap, fine grain soil, and anoxic environment [3]. Under the actions of tidal flush and food chain transport, those stored pollutants can be transferred from the mangroves to the adjacent ecosystems, and even threaten human health $[4,5]$. Therefore, to achieve sustainable development of ecological aspects and socio-economic aspects, it is necessary to understand the situation and source of the pollutants in mangrove ecosystems for future effective management [6,7].

Around the world, mangrove forests have covered over $200,000 \mathrm{~km}^{2}$ of tropical and subtropical coastal areas [8]. Disappearing of mangrove forests have occurred in almost every country that has mangroves, especially in developing countries, such as Brazil, China, Indonesia, Nigeria, and Philippines [9-12]. For China, mangrove forests are mainly distributed from $18^{\circ} \mathrm{N}$ to $27^{\circ} \mathrm{N}$ along the southern coast (including Zhejiang, Fujian, Guangdong, Guangxi, Hainan, Hong Kong, Macao, and Taiwan), with a total area of 22,419 ha in 2015 but which was 48,801 ha in 1973 [13]. Since these mangrove forests are mostly adjacent to agricultural areas or urban areas [14,15], they are vulnerable to surrounding human interference and alien biological invasion [16]. However, mangrove protection has long been ignored by the public until the early 1990s. Since rapid industrialization and agricultural modernization, mangrove forests had suffered significant pollution and degradation, which caused widespread negative effects $[13,17,18]$. Previous studies pointed out that the levels of regional development and environmental management could shape the status of the coastal ecosystem $[19,20]$. To protect the mangrove ecosystems in China, the central government has established 42 mangrove natural reserves and has formulated a lot of laws and regulations in the past 30 years [13].

Previous studies about mangroves of China have investigated many pollutants, including heavy metals, polycyclic aromatic hydrocarbons, and polychlorinated biphenyls, but that is relatively lacking in organochlorine pesticides (OCPs) $[14,15,18]$. Organochlorine pesticides are a series of synthetic chemicals that are recognized as persistent organic pollutants under the Aarhus Protocol and the UNEP Stockholm Convention, and have been extensively used in past decades and have highly contaminated the soil and sediment [21]. Organochlorine pesticides can escape from different sinks and redistribute at the global scale because of its semi-volatility [22]. Given their relatively high lipophilicity, OCPs can be easily absorbed by organisms and transported through the food chain [23]. Besides its toxicity, bioaccumulation, and persistence in nature, several OCPs (e.g., HCH, DDT, and lindane) have been regarded as endocrine-disrupting chemicals [24]. In China, approximately 4.5 million tons of HCHs and 0.27 million tons of DDTs were produced during the 1950s-1980s [25]. Though OCPs were banned from being applied in agriculture by China's central government in 1983, they still existed in a variety of environmental media and agricultural crops [26]. Thus, the distribution and fate of OCPs in different media should be investigated to respond to public health concerns [27-29].

Zhang River Estuary Mangrove National Natural Reserve (ZREMNNR) is the largest natural mangrove forest at the Tropic of Cancer in China [30] and is located in the winter migration path of migratory birds in East Asia [31]. Zhang River Estuary mangrove forests are characterized by the dominant species Kandelia obovata, Avicennia marina, and Aegiceras corniculatum, mixed with other mangrove species (Bruguiera gymnorrhiza and Acanthus ilicifolius) [32,33]. This mangrove is considered to have important social, economic, and ecological value for the local community. Along with intensive agriculture and mariculture practice, varieties of anthropogenic pollutants have been introduced to this area, which causes increased pressure on regional sustainable development [34,35]. It is necessary to understand the distributions and levels of these human-made pollutants, and evaluate the ecological risk of pollutants on the mangrove ecosystem. In this study, we surveyed the distribution of OCPs in surface sediment from ZREMNNR, assessed the ecological risk, and analyzed the possible source of OCPs in this area. Moreover, this study also compared the OCPs levels in ZREMNNR with that in other mangroves of China, and discussed the potential relationship between OCP occurrence and human activity. We hope this study could contribute to the future management of OCPs in mangroves to regulate human activities for source control. 


\section{Materials and Methods}

\subsection{Study Area}

Zhang River Estuary Mangrove National Natural Reserve $\left(23^{\circ} 23^{\prime} 45^{\prime \prime}-23^{\circ} 56^{\prime} 00^{\prime \prime} \mathrm{N}, 117^{\circ} 24^{\prime} 27^{\prime \prime}-\right.$ $117^{\circ} 30^{\prime} 00^{\prime \prime} \mathrm{E}$ ) cover approximately an area of 2360 ha. This national reserve was established in 1997, to promote the natural mangrove forests to recover from serious human disturbances in the past. Zhang River, located in southeastern China, covers an area of approximately $855 \mathrm{~km}^{2}$ (mostly rural) and eventually flowed into the East China Sea and Taiwan Strait via Dongshan Bay. The Zhang River watershed is a typical agricultural zone, and has been reported as one of the higher pesticide (e.g., lindane and DDT) consumption areas of south China [36,37]. The Zhang River irrigate vast stretches of farmland along its course, and play an extremely important role in the region's economic development and ecological health. This area is affected by a subtropical monsoonal climate with a monthly average temperature ranging from $28.9^{\circ} \mathrm{C}$ (in August) to $13.5^{\circ} \mathrm{C}$ (in January). The annual average precipitation over the last ten years was about $1871.2 \mathrm{~mm}$, and the monsoon is accompanied by heavy rainfall during the rainy season from April to September. The tides of the study area ranged from $0.43 \mathrm{~m}$ to $4.67 \mathrm{~m}$, with a mean of $2.32 \mathrm{~m}$ [32].

\subsection{Sampling}

Eighteen surface sediment samples ( $0-5 \mathrm{~cm}$ depth) were collected from the Zhang River Estuary mangrove zone during the low-tide period on April 20, 2007 (Figure 1). Twelve stations located inside the mangrove area, three $(\# 4, \# 5, \# 18)$ at the edge between the mangrove forest and river channel, and three (\#15-17) at the edge between the mangrove and inland. Sediment samples were collected by a stainless-steel dipper and large objects (e.g., leaves, rubbish, and rocks) were removed. Two parallel samples from each station were separately packed by precleaned aluminum foil, and once samples were packed, they were immediately stored at $-20^{\circ} \mathrm{C}$ before future treatment and analysis in the laboratory.

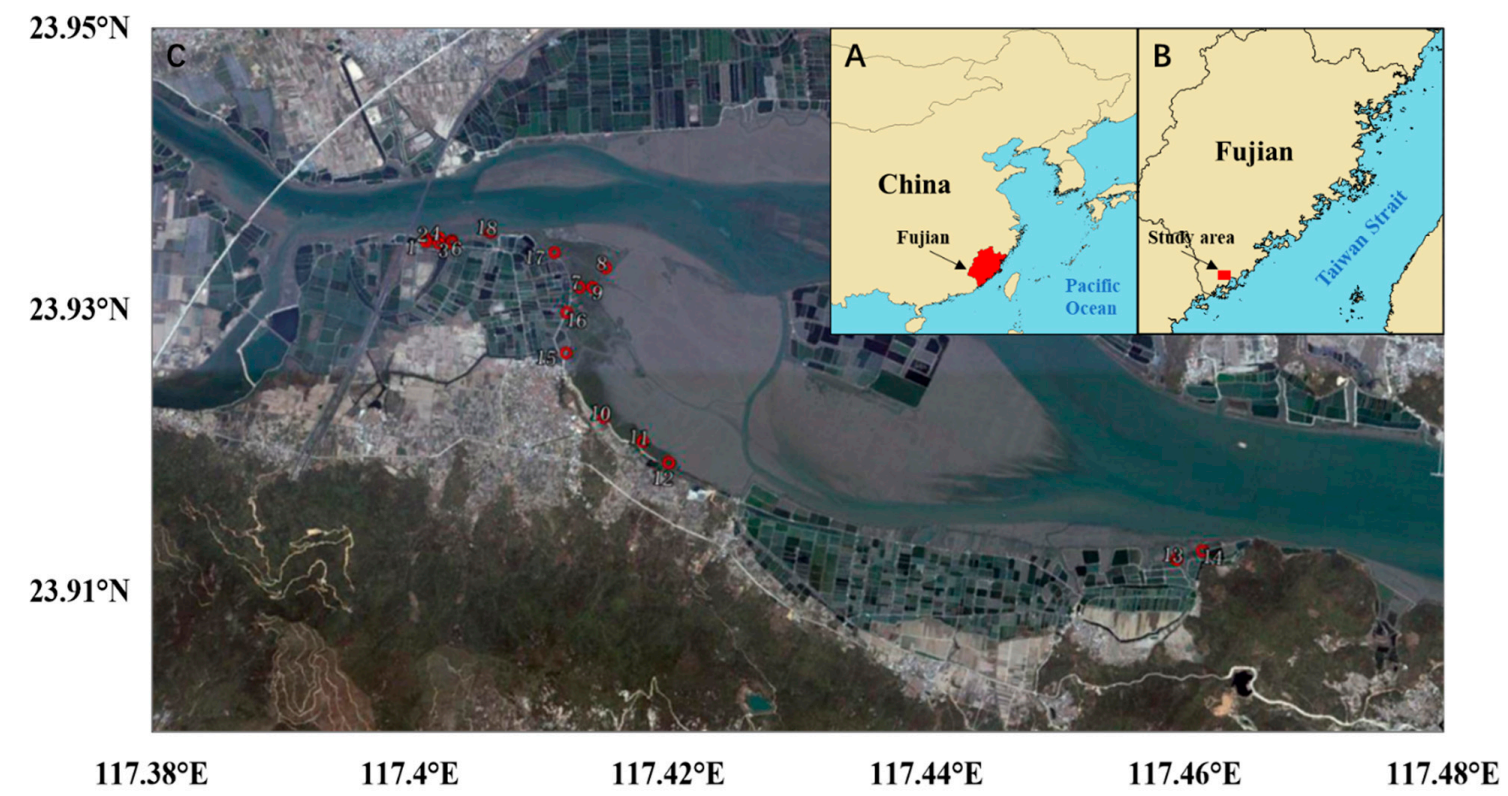

Figure 1. Sampling stations in this study (A: East Asia; B: Fujian Province of China; C: Zhang River mangroves).

\subsection{Extraction and Instrument Analysis}

After being freeze-dried, homogenized, and sieved through a stainless-steel 80 mesh sieve, approximately $20 \mathrm{~g}$ of sediment was Soxhlet-extracted with a mixed solvent of acetone and hexane 
$(160 \mathrm{~mL}, 1: 1 \mathrm{v} / \mathrm{v})$ for $24 \mathrm{~h}$. Before extraction, surrogate standard (polychlorinated biphenyl-209) and activated copper flake (for removing sulfur) were added. The extractions were then concentrated to $1 \mathrm{~mL}$ with a rotary evaporator and cleaned up with a multi-layer silica-aluminum column $(10 \mathrm{~mm}$ inner diameter, from bottom to top filled with $6 \mathrm{~cm}$ of neutral alumina, $2 \mathrm{~cm}$ of neutral silica gel, $5 \mathrm{~cm}$ of $25 \%$ sodium hydroxide silica, $2 \mathrm{~cm}$ of neutral silica gel, $8 \mathrm{~cm}$ of $50 \%$ sulfuric acid silica, and $2 \mathrm{~g}$ of $\left.\mathrm{Na}_{2} \mathrm{SO}_{4}\right)$ by eluting with $80 \mathrm{~mL}$ of hexane and dichloromethane $(7: 3 \mathrm{v} / \mathrm{v})$. The clean extract was concentrated to approximately $0.5 \mathrm{~mL}$ after the solvent exchange with hexane using a rotary evaporator, and the residue was further reduced in volume to $200 \mu \mathrm{L}$ with a gentle nitrogen stream.

An Agilent-6890N gas chromatograph (GC) equipped with a ${ }^{63} \mathrm{Ni}$ electron capture detector (ECD) was used for the experiments to determine the OCP compounds. Manual injection of the $1 \mu \mathrm{L}$ sample was conducted in the high-pressure splitless mode with a purge time of $1.0 \mathrm{~min}$. High purity nitrogen was used as the carrier gas at a flow rate of $2 \mathrm{~mL} / \mathrm{min}$. The GC was equipped with an Agilent HP- 5 capillary column $(30 \mathrm{~m} \times 0.32 \mathrm{~mm}$ inner diameter, $0.25 \mu \mathrm{m}$ film thickness) for separating $\mathrm{OCP}$ congeners. Injector and detector temperatures were set as $250{ }^{\circ} \mathrm{C}$ and $330^{\circ} \mathrm{C}$, respectively. The temperature program was that oven-heated started at $80^{\circ} \mathrm{C}$ with a $2 \mathrm{~min}$ hold, ramped to $190^{\circ} \mathrm{C}$ at a rate of $25^{\circ} \mathrm{C} / \mathrm{min}$, then $5{ }^{\circ} \mathrm{C} / \mathrm{min}$ to $280^{\circ} \mathrm{C}$, and finally $25^{\circ} \mathrm{C} / \mathrm{min}$ to $300^{\circ} \mathrm{C}$ with a 5 min hold. Internal standard calibration (2,4,5,6-tetrachloro-m-xylene and decachlorobiphenyl) with 9 concentrations was employed for the quantification analysis.

\subsection{Quality Assurance and Quality Control}

In this study, procedural blanks, matrix-spiked samples, and parallel samples were processed after the extraction of every 4 samples to check for interference, accuracy, and precision. The recovery rate was measured by spiking with the surrogate standards (17 OCPs in mixture) before extraction. Besides, daily calibration was made for every 12 samples on a GC-ECD to calibrate the instrumental deviation. The mean concentration plus three standard deviations in the blank samples was used as the method detection limits. No background signals were found to be strong enough to interrupt the integration of the target chromatographic peaks, indicating a sample processing procedure free of severe systematic disturbance. The external calibration gave an $R^{2}$ value of more than 0.99 and the method performed well in terms of repeatability. The recovery rates of the matrix-spiked samples and procedural blanks were $70 \%-109 \%$ and $77 \%-114 \%$ (Table S1), respectively.

\subsection{Data Collection}

To discuss the influences of human activities on OCP residues in mangroves of China, 15 kinds of socio-economic variables were collected and seriously checked, including population, population density, urbanization rate, gross domestic product (GDP), per capita GDP, agricultural output value, industrial output value, and value-added service (Table S2); as well as the yields of major agricultural products, including grain, oilseed, sugarcane, vegetable, fruit, and seafood (both mariculture and catch) (Table S3). All the above data were derived from the Statistical Bureau of Fujian Province, Statistical Bureau of Guangdong Province, Statistical Bureau of Guangxi Zhuang Autonomous Region, Statistical Bureau of Hainan Province, Census and Statistics Department of Hong Kong, and Agriculture, Fisheries and Conservation Department of Hong Kong (as seen in the Supplementary Information).

\subsection{Data Analysis}

In this study, Pearson correlation analysis was employed to evaluate the relationship between regional socio-economic levels and OCP concentrations in mangrove sediment. Cluster analysis was used to classify selected Chinese mangroves into different groups based on regional development levels. To identify the key human factor that affects OCP residues in mangrove sediment of China, we used stepwise regression analysis to examine the significance of the selected variables. All the statistical analyses were done using IBM SPSS Statistics 22.0 software (IBM Corporation). 


\section{Results and Discussion}

\subsection{OCPs in the Surface Sediment}

\subsubsection{Concentration of OCPs}

Surface sediment quality can reflect the contaminant situation at the sampling period [38]. Concentrations of organochlorine pesticides in mangrove surface sediments from ZREMNNR are shown in Table 1. OCP compounds that were identified included $\mathrm{HCH}(\alpha-\mathrm{HCH}, \beta-\mathrm{HCH}, \gamma-\mathrm{HCH}$, $\delta$-HCH), DDTs ( $p, p^{\prime}$-DDE, $p, p^{\prime}$-DDD, $p, p^{\prime}$-DDT), and others (aldrin, dieldrin, endrin, endrin aldehyde, heptachlor, heptachlor epoxide, $\alpha$-endosulfan, $\beta$-endosulfan, endosulfan sulfate, and methoxychlor) in this mangrove. Among the sampling stations, the concentrations of EOCPs (dry weight) were in the range of 0.292 to $22.412 \mathrm{ng} / \mathrm{g}$ with an average of $4.503 \mathrm{ng} / \mathrm{g}$, which indicated the conspicuous spatial variation of OCPs. The highest $\sum$ OCPs concentrations were detected at the stations (\#8 and \#9) that where located at the edge of the mangroves facing the sedimentary zone, and the stations that faced the river channel followed. The lower concentrations of OCPs mostly detected at the stations located in the supratidal zone. It showed that transport by river and tidal effect were the OCPs' main sources in this area.

The $\sum \mathrm{HCH}$ ranged from 0.008 to $0.906 \mathrm{ng} / \mathrm{g}$ with an average of $0.240 \mathrm{ng} / \mathrm{g}$. $\beta$-HCH was only detected in five stations, but the levels were higher than other $\mathrm{HCH}$ isomers. Concentrations of $\mathrm{HCH}$ isomers in most stations followed a decreasing order: $\delta-\mathrm{HCH}$ (average of $0.055 \mathrm{ng} / \mathrm{g}$ ) $>\alpha-\mathrm{HCH}$ (average of $0.047 \mathrm{ng} / \mathrm{g}$ ) $>\gamma-\mathrm{HCH}$ (average of $0.033 \mathrm{ng} / \mathrm{g}$ ). The $\sum \mathrm{DDT}$ ranged from not detected (ND) to $4.743 \mathrm{ng} / \mathrm{g}$ with a mean of $0.664 \mathrm{ng} / \mathrm{g}$. Concentrations of DDT and its degradation products in most stations followed: $p, p^{\prime}$-DDT $(0.511 \mathrm{ng} / \mathrm{g})>p, p^{\prime}$-DDE $(0.149 \mathrm{ng} / \mathrm{g})>p, p^{\prime}$-DDD $(0.004 \mathrm{ng} / \mathrm{g})$.

Besides, endrin was only detected (ND-0.233 ng/g) in four stations, while heptachlor epoxide $(\mathrm{ND}-0.019 \mathrm{ng} / \mathrm{g}$ ) and $\alpha$-endosulfan (ND-0.056 ng/g) were both detected with low concentrations. The concentrations of endrin aldehyde and endosulfan sulfate ranged from ND to $3.412 \mathrm{ng} / \mathrm{g}$ and from ND to $12.71 \mathrm{ng} / \mathrm{g}$, respectively, with huge fluctuation among sampling station. The concentrations of dieldrin (0.026-1.030 ng/g), methoxychlor (ND-0.976 ng/g), and $\beta$-endosulfan (ND-0.387 ng/g) highly fluctuated, while the first two compounds had the peak values at Station \#9. The concentrations of aldrin (ND-0.079 ng/g) and heptachlor (ND-0.280 ng/g) were relatively stable among the 18 sampling stations. Among the OCP compounds, HCHs, dieldrin, $\beta$-endosulfan, endrin aldehyde, DDTs, and endosulfan sulfate accounted for the greatest abundance with approximately $61 \%-99 \%$ of $\sum$ OCPs in this mangrove forest. 
Table 1. Concentrations of organochlorine pesticides in mangrove surface sediments collected from Zhang River Estuary Mangrove National Natural Reserve (ZREMNNR), China (ng/g sediment dry weight).

\begin{tabular}{|c|c|c|c|c|c|c|c|c|c|c|c|c|c|c|c|c|c|c|}
\hline Site & $\alpha-\mathrm{HCH}$ & $\beta-\mathrm{HCH}$ & $\gamma-\mathrm{HCH}$ & $\delta-\mathrm{HCH}$ & $p, p^{\prime}$-DDD & $p, p^{\prime}-\mathrm{DDE}$ & $p, p^{\prime}$-DDT & Methoxychlor & Aldrin & Dieldrin & Endrin & $\begin{array}{l}\text { Endrin } \\
\text { Aldehyde }\end{array}$ & Hept. & $\begin{array}{c}\text { Hept. } \\
\text { Epoxide }\end{array}$ & $\alpha$-endo & $\beta$-endo & $\begin{array}{l}\text { Endo } \\
\text { Sulfate }\end{array}$ & $\sum \mathrm{OCPs}$ \\
\hline 1 & 0.083 & 0.133 & 0.009 & ND & 0.003 & 0.030 & 0.043 & ND & 0.007 & 0.087 & ND & ND & 0.280 & 0.003 & 0.004 & 0.077 & ND & 0.759 \\
\hline 2 & 0.040 & ND & 0.033 & 0.067 & 0.007 & ND & 0.081 & ND & 0.007 & 0.154 & ND & ND & 0.020 & ND & 0.004 & 0.170 & ND & 0.583 \\
\hline 3 & 0.025 & ND & 0.016 & ND & 0.005 & ND & 0.108 & ND & 0.033 & 0.118 & ND & ND & 0.038 & ND & 0.010 & 0.114 & ND & 0.467 \\
\hline 4 & 0.044 & 0.816 & 0.013 & 0.033 & 0.008 & 0.110 & 0.234 & 0.099 & 0.019 & 0.239 & 0.047 & 0.294 & 0.028 & ND & 0.013 & 0.187 & 1.034 & 3.218 \\
\hline 5 & 0.124 & ND & 0.118 & 0.168 & 0.007 & 0.228 & 0.051 & 0.098 & 0.029 & 0.165 & 0.017 & 0.322 & 0.008 & ND & 0.010 & 0.162 & 0.478 & 1.985 \\
\hline 6 & 0.026 & ND & 0.024 & 0.051 & 0.012 & 0.304 & 0.232 & 0.076 & 0.024 & 0.372 & ND & 0.763 & 0.009 & ND & 0.021 & 0.279 & 3.025 & 5.218 \\
\hline 7 & ND & 0.596 & 0.023 & ND & ND & 0.897 & 0.076 & 0.279 & 0.079 & 0.536 & ND & 0.629 & 0.013 & 0.010 & 0.048 & ND & 1.407 & 4.593 \\
\hline 8 & 0.009 & 0.203 & 0.041 & 0.030 & 0.002 & 0.368 & 4.373 & 0.223 & 0.046 & 0.934 & ND & 0.566 & 0.078 & 0.004 & 0.056 & 0.043 & 1.924 & 8.900 \\
\hline 9 & 0.233 & ND & 0.102 & 0.043 & ND & 0.466 & 3.255 & 0.976 & 0.035 & 1.030 & 0.233 & 3.412 & 0.046 & ND & 0.017 & ND & 12.71 & 22.56 \\
\hline 10 & 0.040 & ND & 0.023 & ND & ND & ND & ND & ND & 0.036 & 0.180 & ND & 0.524 & 0.007 & ND & 0.012 & ND & ND & 0.822 \\
\hline 11 & 0.011 & ND & 0.005 & ND & 0.002 & ND & 0.135 & 0.018 & 0.072 & 0.070 & 0.007 & 0.337 & 0.012 & ND & 0.004 & 0.043 & 1.093 & 1.809 \\
\hline 12 & 0.021 & ND & 0.031 & 0.021 & ND & 0.073 & 0.048 & 0.025 & 0.004 & 0.091 & ND & 0.274 & 0.015 & 0.002 & 0.017 & ND & 0.628 & 1.250 \\
\hline 13 & 0.028 & ND & 0.029 & 0.033 & 0.001 & 0.068 & 0.096 & 0.012 & 0.005 & 0.180 & ND & 0.165 & 0.013 & 0.007 & 0.023 & 0.032 & ND & 0.692 \\
\hline 14 & 0.011 & ND & 0.040 & ND & ND & 0.121 & ND & ND & 0.028 & 0.138 & ND & 0.621 & 0.006 & ND & 0.009 & ND & ND & 0.974 \\
\hline 15 & 0.023 & ND & 0.027 & 0.516 & 0.016 & ND & 0.472 & 0.020 & 0.031 & 0.026 & ND & 0.976 & 0.043 & 0.019 & 0.012 & 0.387 & 1.627 & 4.195 \\
\hline 16 & ND & ND & 0.008 & ND & ND & ND & ND & ND & 0.007 & 0.134 & ND & 0.134 & 0.003 & ND & 0.006 & ND & ND & 0.292 \\
\hline 17 & 0.077 & ND & 0.034 & ND & ND & ND & ND & ND & 0.010 & 0.103 & ND & 0.126 & ND & ND & ND & ND & ND & 0.350 \\
\hline 18 & 0.042 & 0.171 & 0.015 & 0.028 & ND & 0.024 & ND & ND & ND & 0.153 & ND & 0.220 & 0.033 & 0.002 & 0.034 & ND & 0.759 & 1.481 \\
\hline
\end{tabular}

Hept.: heptachlor; Hept. epoxide: heptachlor epoxide; $\alpha$-endo: $\alpha$-endosulfan; $\beta$-endo: $\beta$-endosulfan; Endo Sulfate: endosulfan sulfate. ND: not detected. 


\subsubsection{Ecological Risk Assessment}

The potential ecological risk of OCPs in ZREMNNR was assessed by comparing the individual compound concentration with some sediment quality guidelines (SQGs). These SQGs included the effects-range low (ERL) and the effects-range median (ERM) [39], as well as the threshold effects level (TEL), probable effects level (PEL) [40], and marine sediment threshold effect level (M-TEL), specified by the National Oceanic and Atmospheric Administration [41] as well as China Marine Sediment Quality (GB 18668-2002) first-class standard criteria (CMSQ I) by the China State Bureau of Quality and Technical Supervision [42]. The thresholds of the above sediment quality guidelines for OCPs are listed in Table 2.

Table 2. The thresholds of some sediment quality guidelines for organochlorine pesticides (OCPs) (ng/g, dry weight).

\begin{tabular}{ccccccc}
\hline Compound & ERL $^{\mathbf{a}}$ & ERM $^{\mathbf{a}}$ & TEL $^{\mathbf{b}}$ & PEL $^{\mathbf{b}}$ & M-TEL $^{\mathbf{c}}$ & CMSQ I $^{\mathbf{d}}$ \\
\hline$\gamma$-HCH & - & - & 0.94 & 1.38 & 0.32 & - \\
$\sum$ HCHs & - & - & - & - & - & 500 \\
$p, p^{\prime}$-DDD & 2 & 20 & 3.54 & 8.51 & 1.22 & - \\
$p, p^{\prime}$-DDE & 2.2 & 27 & 1.42 & 6.75 & 2.07 & - \\
$p, p^{\prime}-\mathrm{DDT}$ & 1 & 7 & 1.79 & - & 1.19 & - \\
$\sum$ DDTs & 1.58 & 46.1 & 7 & 4450 & 3.89 & 20 \\
Dieldrin & 0.02 & 8 & 2.85 & 2.85 & 0.72 & - \\
Endrin & 0.02 & 45 & 2.67 & 62.4 & - & - \\
Heptachlor epoxide & - & - & 0.6 & 2.74 & - & - \\
\hline
\end{tabular}

ERL: effects-range low; ERM: effects-range median; TEL: threshold effects level; PEL: probable effects level; M-TEL: marine sediment threshold effects level; CMSQ I: China Marine Sediment Quality first-class; "_": no data. ${ }^{\text {a }}$ [39]; ${ }^{\mathrm{b}}[40]{ }^{\mathrm{c}}[41] ;{ }^{\mathrm{d}}[42]$.

Under the guidelines of ERL, the concentrations of $p, p^{\prime}$-DDT and $\sum$ DDTs in only Station \#8 and Station \#9 were detected to exceed the threshold values. Furthermore, the exceeded values of endrin were detected in Station \#4 and Station \#9, and that of dieldrin were observed in all stations. The concentrations of $p, p^{\prime}$-DDT and dieldrin in Station \#8 and Station \#9 also exceeded under the guideline of M-TEL. None of the OCP compounds was detected to exceed the threshold of ERM, TEL, and PEL, meaning that their biological risk was negligible under the above sediment quality guidelines. According to CMSQ I, the natural reserve applies to the first-class quality standard that $\sum D D T s$ should be less than $20 \mathrm{ng} / \mathrm{g}$, and $\sum \mathrm{HCH}$ should be less than $500 \mathrm{ng} / \mathrm{g}$ [42]. In terms of DDTs and HCHs in Zhang River Estuary mangrove, both qualities met the first-class requirements under the guideline value.

Compared with the thresholds of the above sediment quality guidelines, we concluded that the ecological risk of OCPs in ZREMNNR is still at a low level.

\subsubsection{Source of OCPs}

The typical technical HCHs contain $60 \%-70 \%$ of $\alpha-\mathrm{HCH}, 5 \%-12 \%$ of $\beta-\mathrm{HCH}, 10 \%-12 \%$ of $\gamma-\mathrm{HCH}$, and $6 \%-10 \%$ of $\delta-\mathrm{HCH}$ [43], which means the mixing ratio of $\alpha-\mathrm{HCH} / \gamma-\mathrm{HCH}$ lies between 4 and 7 [44]. Agricultural $\mathrm{HCHs}$ (lindane) commonly contains $99 \% \gamma-\mathrm{HCH}$ [45]. Moreover, the degradation rate of $\mathrm{HCH}$ isomers follow $\alpha-\mathrm{HCH}>\gamma-\mathrm{HCH}>\delta-\mathrm{HCH}>\beta-\mathrm{HCH}$ [46], and $\gamma-\mathrm{HCH}$ can be converted to $\alpha-\mathrm{HCH}$ and even $\beta-\mathrm{HCH}$ in a given environment $[47,48]$. As such, the composition proportion of $\mathrm{HCH}$ isomers can be used to identify the potential source. As shown in Figure 2, the ratios of $\alpha-\mathrm{HCH} / \gamma-\mathrm{HCH}$ varied from ND to 9.22, with most being less than 4 (except in Station \#1). It is inferred that $\gamma-\mathrm{HCH}$ was almost not used for agricultural purposes in the Zhang River basin. $\beta-\mathrm{HCH}$ was detected in a few stations and the average ratio of $\alpha-\mathrm{HCH} / \beta-\mathrm{HCH}$ was 0.24 . As $\beta-\mathrm{HCH}$ was the most stable and relatively resistant to microbial degradation, the ratio and the relatively high concentration indicated 
that no extra industrial $\mathrm{HCHs}$ input was recently received in the study area. According to the above, $\mathrm{HCHs}$ residues in surface sediment were mainly from the soil erosion [49,50].

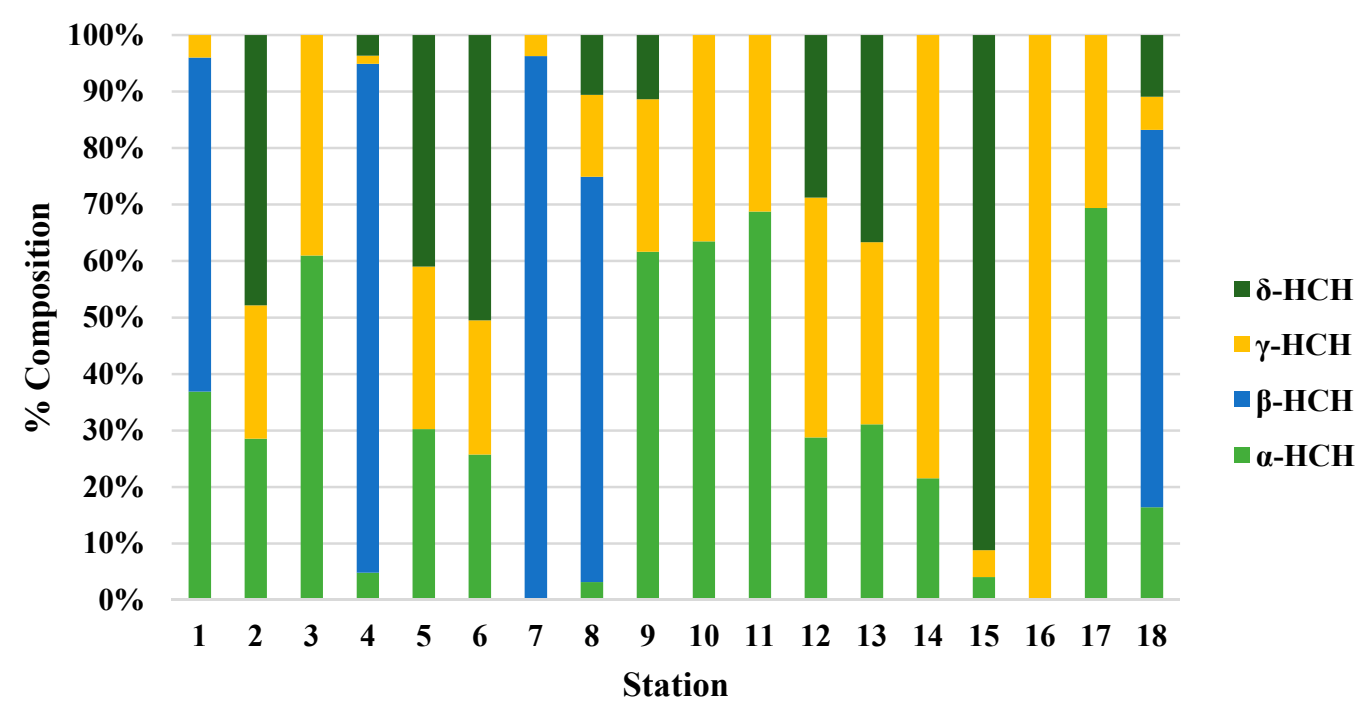

Figure 2. The composition of $\mathrm{HCH}$ isomers in mangrove surface sediments from Zhang River Estuary.

DDT can be degraded into DDD and DDE in anaerobic and aerobic conditions, respectively. The relative concentration of DDD compared to DDE can show the main degradation pathway of DDT [51], so the ratio of parent to metabolites can reveal the recent DDT source [52,53]. At most stations of the study area, the values of DDD/DDE were far less than 1 and there were five sites where DDD was not detectable (Figure 3). It is indicated that most of the historical input DDT degraded under aerobic conditions before deposition. In the stations where DDT was detected, most ratios of $\mathrm{DDT} /(\mathrm{DDD}+\mathrm{DDE})$ were more than 1, which inferred that DDT had been recently used around the study area. DDT was banned from agricultural use in China since 1983, but it was still legally used for malaria prevention and dicofol production until 2009 [54]. As a previous survey reported, approximately $8770 \mathrm{t}$ DDT was put into the environment from dicofol use in China during 1988 2002 [55]. Another possible source was DDT-containing antifouling paints, which was the primary choice for motorboat maintenance and accounted for 4\% DDT consumption in China [56]. Since Zhang River Estuary and the sequential bay was a highly productive mariculture area with a large number of motorboats, part of the DDT-containing antifouling paint can move into the mangrove with the tidal effect.

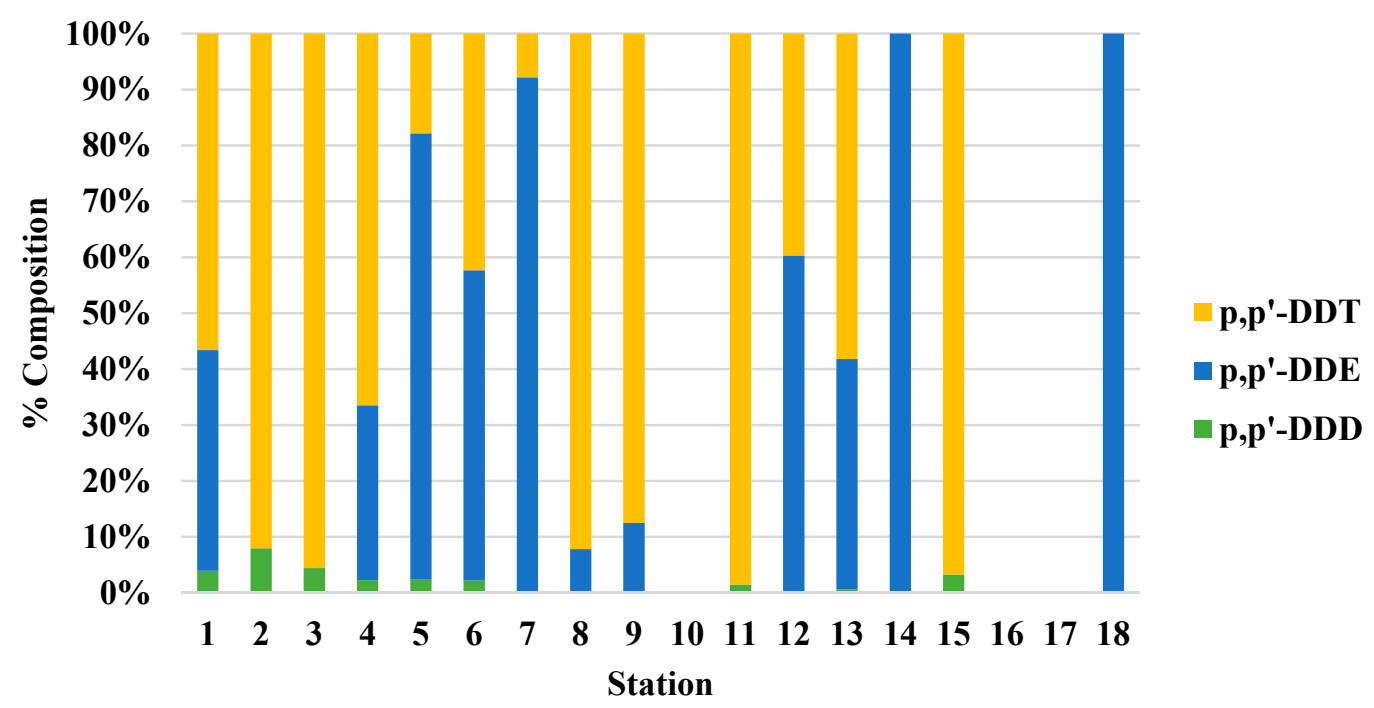

Figure 3. The composition of DDT isomers in mangrove surface sediments from Zhang River Estuary. 
The typical commercial endosulfan consists of $70 \% \alpha$-endosulfan and 30\% $\beta$-endosulfan [57], and both can be degraded into the more toxic substance, endosulfan sulfate. The concentration of endosulfan sulfate (average $1.371 \mathrm{ng} / \mathrm{g}$ ) was much higher than $\alpha$-endosulfan $(0.017 \mathrm{ng} / \mathrm{g}$ ) and $\beta$-endosulfan $(0.083 \mathrm{ng} / \mathrm{g})$, which indicated most of the endosulfan isomers degraded. The ratios of the two isomers of endosulfan ranged from 0.02 to 1.30 (Figure S1), except Station 10, 14, and 16 ( $\beta$-endosulfan was undetected). Given that $\beta$-endosulfan was more conservative than $\alpha$-endosulfan [58] and the degradation product endosulfan sulfate was dominant in surface sediments, there was no reason for endosulfan use recently.

\subsection{OCPs Concentration in Mangrove Sediment of China}

In this section, we compared the residue levels of OCPs in China's mangrove sediments based on published articles, analyzed their distribution pattern, and discussed the potential anthropogenic factors for OCP distribution.

\subsubsection{The Distribution of OCPs}

Based on the data collection from the previous studies, the OCP residue levels in different mangrove sediments were from 0.29 to $105.63 \mathrm{ng} / \mathrm{g}$ during the past 20 years (Table 3). The highest detected values of OCPs were in Mai Po Marshes [5,59] and Jiulong River Estuary [23,60], followed by Leizhou Peninsula [61] and Deep Bay [62]. The sediment OCP concentrations in Dongzhai Harbor [4,63], Sanya coast [4], Nansha Wetland [64,65], and Zhang River Estuary (this study) were significantly lower than those above areas. Conspicuously, OCP concentrations in estuarial sediments were higher than that in non-estuarial sediments (Figure $4 \mathrm{a}, \mathrm{b}$ ), especially those watersheds of the upper river with existing high-intensive agricultural activities [49]. 
Table 3. Comparison of OCP residue levels in surface sediments from different mangrove zones, China (ng/g dry weight).

\begin{tabular}{|c|c|c|c|c|c|c|c|c|c|c|}
\hline \multirow{2}{*}{ Area } & \multirow{2}{*}{ Abbr. } & \multirow{2}{*}{ Province } & \multirow{2}{*}{ Sampling Time } & \multicolumn{2}{|c|}{$\sum \mathrm{HCHs}$} & \multicolumn{2}{|c|}{$\sum$ DDTs } & \multicolumn{2}{|c|}{$\sum$ OCPs } & \multirow{2}{*}{ Source } \\
\hline & & & & Range & Mean & Range & Mean & Range & Mean & \\
\hline Deep Bay ${ }^{a}$ & DPB & Guangdong/Hong Kong & Feb. 2004 & $0.22-1.07$ & 0.50 & $2.92-82.3$ & 20.2 & $3.91-84.5$ & 23.2 & [62] \\
\hline Dongzhai Harbor ${ }^{b}$ & $\mathrm{DZH}$ & Hainan & Sep. 2005 & $0.06-2.30$ & 0.53 & $0.09-2.13$ & 0.57 & $0.31-7.36$ & 1.96 & [63] \\
\hline Dongzhai Harbor ${ }^{c}$ & $\mathrm{DZH}$ & \multirow{2}{*}{ Hainan } & \multirow{2}{*}{ Aug. 2014} & $0.01-0.09$ & 0.05 & $1.15-2.90$ & 2.10 & $1.07-3.97$ & 2.90 & \multirow{2}{*}[4]{} \\
\hline Sanya coast & SYC & & & $0.01-0.14$ & 0.07 & $2.17-7.67$ & 3.02 & $2.32-9.48$ & 4.21 & \\
\hline Jiulong River Estuary ${ }^{d}$ & JRE & Fujian & May and Jun. 2009 & $0.31-1.85$ & 1.05 & $1.28-91.2$ & 37.7 & 13.6-106 & 50.7 & {$[60]$} \\
\hline Jiulong River Estuary & JRE & Fujian & Oct. 2013 & - & - & $21-84$ & 52 & - & - & [23] \\
\hline Leizhou Peninsula ${ }^{b}$ & LZP & Guangdong & Jul. and Nov. 2005 & - & 0.07 & $0.75-112$ & 27.8 & - & 28.9 & [61] \\
\hline Mai Po Marshes e & MPM & Guangdong/Hong Kong & 1997 & $9.7-28.5$ & 16.2 & $3.4-14.2$ & 8.2 & $29.1-73.9$ & 45.0 & [59] \\
\hline \multirow{2}{*}{ Mai Po Marshes ${ }^{f}$} & \multirow{2}{*}{ MPM } & \multirow{2}{*}{ Guangdong/Hong Kong } & Jun. 2002 & $0.44-8.96$ & 4.35 & $2.0-31$ & 16.2 & $6.89-73.7$ & 39.5 & \multirow{2}{*}{ [5] } \\
\hline & & & Jan. 2003 & $0.20-8.58$ & 3.12 & $1.4-19$ & 17.5 & $10.6-95.7$ & 58.8 & \\
\hline Nanliu Estuary & NLE & Guangxi & Dec. 2011 & - & - & $2.9-3.7$ & $\sim 3$ & - & - & [66] \\
\hline Nansha Wetland ${ }^{b}$ & NSW & Guangdong & Dec. 2011 & $0.36-0.62$ & 0.51 & $5.61-7.50$ & 6.5 & - & $\sim 7$ & [64] \\
\hline Nansha Wetland ${ }^{b}$ & NSW & Guangdong & Mar. 2015 & $0.67-7.29$ & 3.35 & $2.37-9.40$ & 5.23 & $3.1-16.0$ & 8.58 & [65] \\
\hline Zhang River Estuary g & ZRE & Fujian & Apr. 2007 & $0.01-0.91$ & 0.24 & ND-4.74 & 0.66 & $0.29-25.4$ & 4.50 & This study \\
\hline
\end{tabular}

\footnotetext{
a 10 OCP compounds were reported. ${ }^{b} 8$ OCP compounds were reported. c 22 OCP compounds were reported. ${ }^{d} 24$ OCP compounds were reported. ${ }^{\text {e }} 13$ OCP compounds were reported.
f 22 OCP compounds were reported. $\mathrm{g} 17$ OCP compounds were reported. ND: not detected. “-”: no data.
} 

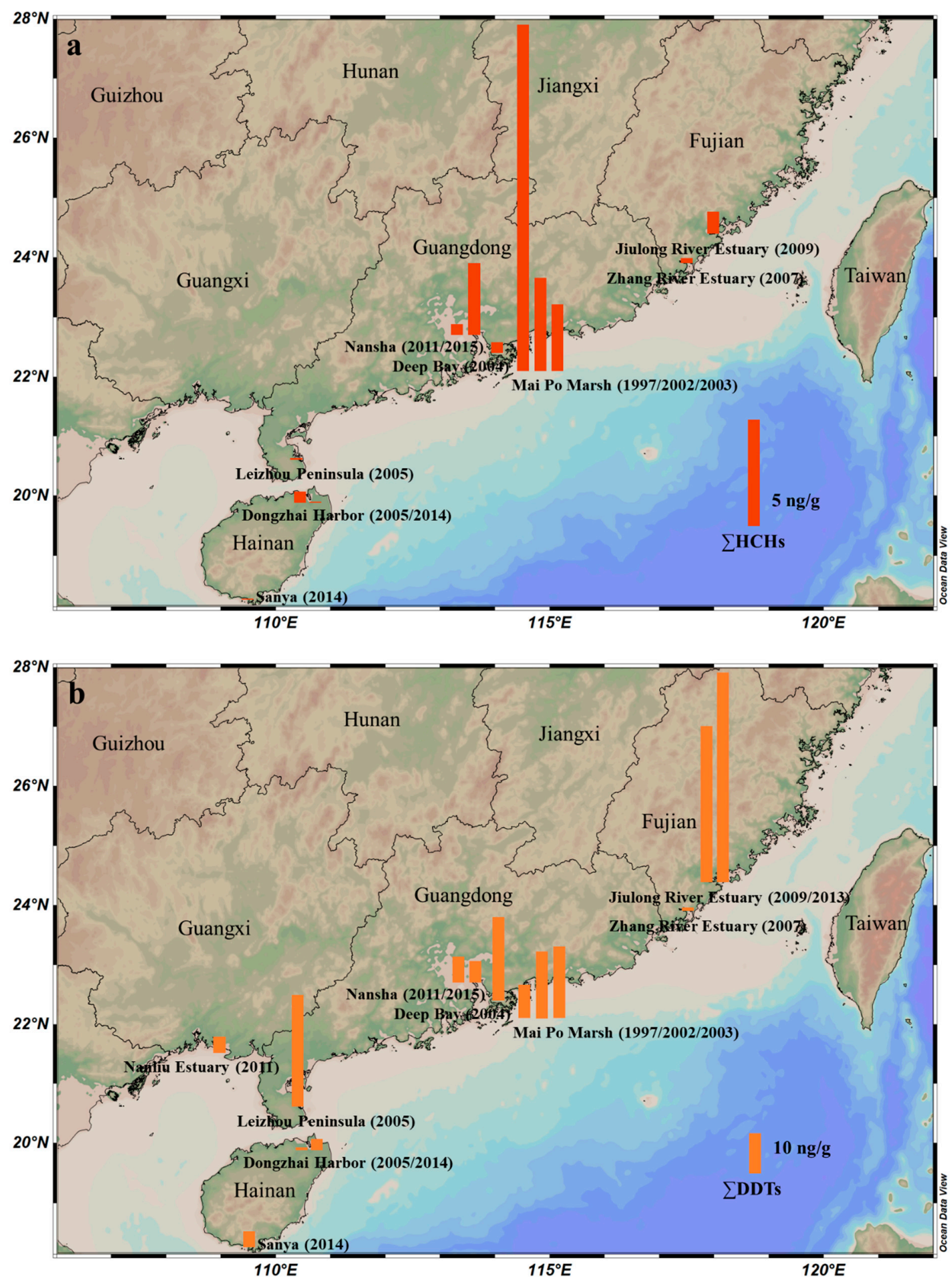

Figure 4. The average concentrations of $\sum \mathrm{HCHs}(\mathbf{a})$ and $\sum \mathrm{DDTs}(\mathbf{b})$ in mangrove surface sediment, China (the numbers in brackets represent the sampling year).

For HCHs, the residue values ranged from 0.01 to $28.5 \mathrm{ng} / \mathrm{g}$ among the different mangrove sediments. It is worth noting that $\mathrm{HCHs}$ residues in the mangroves near the Pearl River Estuary were higher than that in other regions; the relatively higher level could be linked to higher consumption per unit area of technical HCHs and lindane of Guangdong during the 1960s-1980s [36]. The HCH residue levels of Mai Po Marsh gradually decreased during 1997-2003, indicating that $\mathrm{HCH}$ application had been effectively cut down. HCH residues of Nansha Wetland in 2015 was higher than that in 2011, meaning this area may still be affected by illegal use of HCHs [67]. Compared with the HCH 
concentration of Taihu Lake (average of $0.3-5.3 \mathrm{ng} / \mathrm{g}$ ), an inland lake affected by surrounding intensive agricultural activities [68], the residue levels of China's mangrove sediment indicate that they were still affected by past $\mathrm{HCH}$ usage.

For DDTs, the reported values among different mangrove sediments ranged from ND to $112 \mathrm{ng} / \mathrm{g}$, which was one or two orders of magnitude higher than that of HCHs. Given the total usage of DDTs was far less than that of HCHs, the residue level meant that DDTs was still widely used in China [69]. Unlike HCHs, the higher residues of DDTs appeared at the Jiulong River Estuary, followed by Leizhou Peninsula, Deep Bay, and Mai Po Marsh. Despite the runoff transportation, another possible explanation for DDTs distribution is the precipitation from DDT-containing antifouling paint, since the above areas are all important fishery and mariculture areas. Similar to $\mathrm{HCHs}$, the DDT residue level in Zhang River Estuary was also lower than that in other areas (Figure $4 b$ ).

\subsubsection{The Potential Human Influences for $\mathrm{HCH}$ and DDT Residues}

Before data analysis, (1) we premised that $\mathrm{HCH}$ and DDT residues in mangrove sediment were mainly from the human activities of the surrounding area, in which case that of the upper river was neglected; this is because mangroves have higher primary productivity and poorer hydrodynamic conditions [1], resulting in buried organic matters in mangrove that are mainly from the surrounding environment. (2) Given the accessibility and integrity of the data, meanwhile, the surrounding area only refers to the prefecture-level administrative region adjacent to the mangroves (Tables S2 and S3). Since the different surveyed areas had different statistical periods and items, we could not collect the available data under the county-level administrative region or below. (3) Given the disturbance of price changes, all economic data have been adjusted according to the consumer price index and with the year 2005 as the base period.

Based on collected socio-economic data, hierarchical cluster analysis was used to classify the above mangroves. Cluster analysis rendered a dendrogram where the areas were divided into two clusters, and each cluster could be further divided into two sub-clusters at $D_{\text {link }} / D_{\max }<40 \%$ and $20 \%$, respectively (Figure S2). Cluster 1 included Mai Po Marsh, Deep Bay, Nansha Wetland, and Jiulong River Estuary (in 2013), representing the areas with a higher GDP, more densely populated, and with a higher urbanization rate, namely the developed area. The sub-cluster, including Mai Po Marsh and Deep bay, was more developed than that of Nansha Wetland and Jiulong River Estuary. Nanliu River Estuary, Dongzhai Harbor, Sanya coast, Leizhou Peninsula, Zhang River Estuary, and Jiulong River Estuary (in 2009) were classified into Cluster 2, which represented the areas with a lower GDP, smaller populations, a lower urbanization rate, and where agriculture was still important, namely the developing areas.

Pearson correlation analysis was used to evaluate the relationship between socio-economic levels and OCP (e.g., HCHs and DDTs) concentrations in surface sediment of mangroves (Table S4). The results showed that $\mathrm{HCH}$ concentration had a significant positive correlation with value-added service $(p=0.043)$ and per capita GDP $(p=0.033)$. Interestingly, $\mathrm{HCH}$ concentration had nothing to do with any agricultural crop at the surveyed time, although the source was known as technical $\mathrm{HCH}$ and lindane used for agriculture practice $[4,64]$. The differences in $\mathrm{HCH}$ residues among the areas may be attributed to the different economic levels of the surrounding areas. It has been proved that pesticide consumption was proportional to the local socio-economic level [70]. Among the surveyed mangroves, those along the developed surrounding areas are commonly located in estuaries with large watersheds, such as Pearl River and Jiulong River (Figure 4a and Table 1). On the one hand, the character of the location means mangroves can receive and bury more $\mathrm{HCH}$ due to more pesticide consumption [69,71]. On the other hand, the farmers in the developed area could afford more pesticides than those in developing areas. As a consequence, considerably higher $\mathrm{HCHs}$ were applied and thus were residual in the developed areas (Cluster 1), more so than in the developing areas (Cluster 2).

Different from HCHs, the correlation coefficient (Table S4) indicated that DDT concentration had a significant positive correlation with local agricultural output value $(p=0.019)$, fruit output 
$(p=0.008)$, and mariculture output $(p=0.034)$. This result indirectly shows that the pesticides and antifouling paints containing DDT were still widely consumed in the south of China for fruit planting and mariculture operation [72,73]. A stepwise regression was used to identify the key agricultural production that affected DDT residues in mangrove sediment. The result of the stepwise regression was an ordinary least-squares estimation of a linear multivariate model, including only variables significant at or above the $5 \%$ level.

As shown in Table 4, DDT residues in mangrove sediment was more likely from fruit planting, which matched the fact of high usage of DDT for fruit growing in the south of China $[37,55]$. The determinate coefficient $\left(R^{2}=0.452\right)$ was relatively low; however, it meant existing additional factors affected DDT residues. Further, developed areas and developing areas were respectively analyzed to further identify the key factor for DDT residues in mangrove sediment. For the developed areas, mariculture was more significant than fruit planting, with a high accumulated $R^{2}$ value (0.944) of the regression model (Table S5). For the developing areas, vegetable production was the significant factor affecting DDT residues, with a moderate $R^{2}$ value (0.578) of the regression model (Table S6). Obviously, rising incomes, urbanization, and export trade have boosted the demands for seafood, fruits, and other non-staple foods, and have had a defining effect on the crop-growing structure in the developed areas, where farmers have shifted between plant species to meet demands [74,75]. To achieve higher yields, it is inevitable to use more pesticides and antifouling paints in agricultural practice, resulting in more DDTs entering into the coastal environment [56,73]. On the contrary, absent capital input and market demand could drive farmers to plant the crop of higher labor input in the developing areas, like vegetables [76,77]. A study conducted in Guangdong found that the detection rates of DDT residues in vegetables were up to $93 \%$, showing that DDTs were ubiquitous contaminants in vegetable production [78]. Several studies also confirmed that DDTs were recently used illegally in southern coastal regions, despite these chemicals having been banned decades ago [67,71,79].

Table 4. The stepwise regression result of $\sum$ DDTs and agricultural production yield.

\begin{tabular}{cccccc}
\hline Model & $\boldsymbol{\beta}$ & $\boldsymbol{t}$-Value & $\boldsymbol{p}$-Value & \multicolumn{2}{c}{ Accumulated } \\
& & & & $\boldsymbol{R}^{\mathbf{2}}$ \\
\hline Constant & 6.349 & 1.551 & 0.147 & \\
\hline \multicolumn{7}{c}{ Variables entered } \\
\hline Fruit & 0.102 & 3.145 & 0.008 & 0.672 & 0.452 \\
\hline \multicolumn{7}{c}{ Variables removed } \\
Grain & -0.539 & -1.258 & 0.234 & \\
Oilseed & 0.124 & 0.451 & 0.661 & \\
Vegarcane & 0.055 & 0.244 & 0.812 & \\
Aquaculture & -0.167 & -0.561 & 0.586 & \\
Catch yield & 0.141 & -0.762 & 0.462 & \\
\hline
\end{tabular}

In conclusion, $\mathrm{HCH}$ concentrations in mangrove sediment had a positive correlation with the socio-economic level of the surrounding areas. The reason was that the developed areas have consumed more pesticides (including $\mathrm{HCHs}$ ) through agricultural activities than the developing areas. Based on the statistical analysis, there was a highly positive correlation between fruit production of the surrounding area and DDT residues in mangrove sediment. Antifouling paint contributed more DDT residues than DDTs-containing pesticides in the developed areas, whereas pesticide use for vegetable planting was a significant source of DDTs in the developing areas.

\section{Conclusions}

Zhang River Estuary Mangrove National Natural Reserve is the largest and best protected natural mangrove forest at the Tropic of Cancer in China, with the highest abundance in species. In this 
study, 17 organochlorine pesticides in surface sediment from ZREMNNR were detected, and HCHs, dieldrin, $\beta$-endosulfan, endrin aldehyde, DDTs, and endosulfan sulfate accounted for approximately $61 \%-99 \%$ of the $\sum$ OCPs. The highest detected value of OCPs occurred in the subtidal zone, meaning that river transport and tidal effects were their main distribution sources. It was observed that the concentrations of $\mathrm{HCH}$ isomers were in the following decreasing order: $\alpha-\mathrm{HCH}>\beta-\mathrm{HCH}>\delta-\mathrm{HCH}>$ $\gamma-\mathrm{HCH}$, and that of the DDT isomers followed $p, p^{\prime}$-DDT $>p, p^{\prime}$-DDE $>p, p^{\prime}$-DDD. According to the analysis of isomer ratios, $\gamma-\mathrm{HCH}$ (lindane) and endosulfan were rarely used around this mangrove in recent times, but DDTs was still illegally used. Compared with other mangrove forests in China, the OCP residue levels in mangrove sediment of ZREMNNR is at a much lower level.

Among the mangroves of China, OCP residue levels in estuarial mangroves were higher than that in non-estuarial mangroves, especially those watersheds among high-intensity agricultural activities. Although China's central government banned OCP usage for agricultural practice in 1983, the higher residue levels suggest that DDT was still illegally used. The results of the statistical analysis shown that fruit planting, as well as mariculture operation in the developed areas and vegetable planting in the developing areas, had a positive relation with DDT residue levels in mangrove sediments of China. Oppositely, $\mathrm{HCH}$ residues in mangrove sediments mainly were derived from historical rather than current consumption, and generally, the higher levels appeared in the developed areas. We appeal to the local administrator to strengthen the control of illegal DDT use in agricultural practices to avoid potential ecological risks.

Supplementary Materials: The following are available online at http://www.mdpi.com/2071-1050/12/7/3016/s1, Figure S1. The compositions of endosulfan and endosulfan sulfate in mangrove surface sediments from Zhang River Estuary. Figure S2. Dendrogram of the socio-economic levels of the areas around surveyed mangroves at OCPs sampling time (the numbers in brackets represent the survey year). Table S1. Recovery rates of individual OCP in samples and procedural blanks, and detection limit. Table S2. The socio-economic development levels of the areas around surveyed mangrove, China. Table S3. The yields of major agricultural products of the areas around surveyed mangrove, China. Table S4. The Pearson correlation coefficient of HCHs, DDTs and human activities. Table S5. The stepwise regression result of $\sum$ DDTs and agricultural yield of Cluster 1. Table S6. The stepwise regression result of $\sum$ DDTs and agricultural yield of Cluster 2.

Author Contributions: Conceptualization, M.C.; data curation, S.H., J.S., X.L. (Xiaoyan Liu) and B.Q.; formal analysis, K.C., B.C. and X.L. (Xiaoyan Liu); funding acquisition, M.C.; investigation, Y.W., B.C., X.L. (Xiaomeng Li), S.H. and J.S.; methodology, C.Q.; project administration, M.C.; software, K.C.; supervision, M.C. and H.K.; visualization, K.C. and Y.W.; writing-original draft, K.C., Y.W. and X.L. (Xiaomeng Li); writing-review and editing, K.C. and M.C. All authors have read and agreed to the published version of the manuscript.

Funding: This research was funded by the National Natural Science Foundation of China $(41776088,41976216)$; the National Social Science Fund of China (17VHQ012); Marine Science Base Scientific Research Training and Scientific Research Ability Enhancement Project of Xiamen University (J1210050).

Acknowledgments: We also thank the Administrative Bureau of Zhang River Estuary Mangrove National Natural Reserve Fujian. The authors thank Shaozhou Xie, Rongyuan Liang and Bozhou Fang for their contributions.

Conflicts of Interest: The authors declare no conflict of interest.

\section{References}

1. Lewis, M.; Pryor, R.; Wilking, L. Fate and effects of anthropogenic chemicals in mangrove ecosystems: A review. Environ. Pollut. 2011, 159, 2328-2346. [CrossRef] [PubMed]

2. Vo, Q.T.; Kuenzer, C.; Vo, Q.M.; Moder, F.; Oppelt, N. Review of valuation methods for mangrove ecosystem services. Ecol. Indic. 2012, 23, 431-446. [CrossRef]

3. Christensen, S.M.; Tarp, P.; Hjortsø, C.N. Mangrove forest management planning in coastal buffer and conservation zones, Vietnam: A multimethodological approach incorporating multiple stakeholders. Ocean Coast. Manag. 2008, 51, 712-726. [CrossRef]

4. Qiu, Y.-W.; Qiu, H.-L.; Zhang, G.; Li, J. Bioaccumulation and cycling of organochlorine pesticides (OCPs) and polychlorinated biphenyls (PCBs) in three mangrove reserves of south China. Chemosphere 2019, 217, 195-203. [CrossRef] [PubMed]

5. Wong, H.L.; Giesy, J.P.; Lam, P.K.S. Organochlorine Insecticides in Mudflats of Hong Kong, China. Arch. Environ. Contam. Toxicol. 2006, 50, 153-165. [CrossRef] 
6. Bodin, N.; N'Gom Ka, R.; Le Loc'h, F.; Raffray, J.; Budzinski, H.; Peluhet, L.; Tito de Morais, L. Are exploited mangrove molluscs exposed to Persistent Organic Pollutant contamination in Senegal, West Africa? Chemosphere 2011, 84, 318-327. [CrossRef]

7. Ellison, A.M.; Farnsworth, E.J. Anthropogenic Disturbance of Caribbean Mangrove Ecosystems: Past Impacts, Present Trends, and Future Predictions. Biotropica 1996, 28, 549-565. [CrossRef]

8. Duke, N.C.; Meynecke, J.-O.; Dittmann, S.; Ellison, A.M.; Anger, K.; Berger, U.; Cannicci, S.; Diele, K.; Ewel, K.C.; Field, C.D.; et al. A World Without Mangroves? Science 2007, 317, 41-42. [CrossRef]

9. Chen, L.; Wang, W.; Zhang, Y.; Lin, G. Recent progresses in mangrove conservation, restoration and research in China. J. Plant Ecol. 2009, 2, 45-54. [CrossRef]

10. Ferreira, A.C.; Lacerda, L.D. Degradation and conservation of Brazilian mangroves, status and perspectives. Ocean Coast. Manag. 2016, 125, 38-46. [CrossRef]

11. Onyena, A.P.; Sam, K. A review of the threat of oil exploitation to mangrove ecosystem: Insights from Niger Delta, Nigeria. Glob. Ecol. Conserv. 2020, 22, e00961. [CrossRef]

12. Polidoro, B.A.; Carpenter, K.E.; Collins, L.; Duke, N.C.; Ellison, A.M.; Ellison, J.C.; Farnsworth, E.J.; Fernando, E.S.; Kathiresan, K.; Koedam, N.E.; et al. The Loss of Species: Mangrove Extinction Risk and Geographic Areas of Global Concern. PLoS ONE 2010, 5, e10095. [CrossRef] [PubMed]

13. Jia, M.; Wang, Z.; Zhang, Y.; Mao, D.; Wang, C. Monitoring loss and recovery of mangrove forests during 42 years: The achievements of mangrove conservation in China. Int. J. Appl. Earth Obs. Geoinf. 2018, 73, 535-545. [CrossRef]

14. Tam, N.F.Y. Pollution Studies on Mangroves in Hong Kong and Mainland China. In The Environment in Asia Pacific Harbours; Wolanski, E., Ed.; Springer: Dordrecht, The Netherlands, 2006; pp. 147-163.

15. Vane, C.H.; Harrison, I.; Kim, A.; Moss-Hayes, V.; Vickers, B.; Hong, K. Organic and metal contamination in surface mangrove sediments of South China. Mar. Pollut. Bull. 2009, 58, 134-144. [CrossRef] [PubMed]

16. Santos, L.C.M.; Matos, H.R.; Schaeffer-Novelli, Y.; Cunha-Lignon, M.; Bitencourt, M.D.; Koedam, N.; Dahdouh-Guebas, F. Anthropogenic activities on mangrove areas (São Francisco River Estuary, Brazil Northeast): A GIS-based analysis of CBERS and SPOT images to aid in local management. Ocean Coast. Manag. 2014, 89, 39-50. [CrossRef]

17. Wu, H.; Peng, R.; Yang, Y.; He, L.; Wang, W.; Zheng, T.; Lin, G. Mariculture Pond Influence on Mangrove Areas in South China: Significantly Larger Nitrogen and Phosphorus Loadings from Sediment Wash-out than from Tidal Water Exchange. Aquaculture 2014, 426-427, 204-212. [CrossRef]

18. Zhang, Z.-W.; Xu, X.-R.; Sun, Y.-X.; Yu, S.; Chen, Y.-S.; Peng, J.-X. Heavy metal and organic contaminants in mangrove ecosystems of China: A review. Environ. Sci. Pollut. Res. 2014, 21, 11938-11950. [CrossRef]

19. Cai, M.; Liu, Y.; Chen, K.; Huang, D.; Yang, S. Quantitative analysis of anthropogenic influences on coastal water - A new perspective. Ecol. Indic. 2016, 67, 673-683. [CrossRef]

20. Chen, K.; Liu, Y.; Huang, D.; Ke, H.; Chen, H.; Zhang, S.; Yang, S.; Cai, M. Anthropogenic activities and coastal environmental quality: A regional quantitative analysis in southeast China with management implications. Environ. Sci. Pollut. Res. 2018, 25, 3093-3107. [CrossRef]

21. Wöhrnschimmel, H.; Scheringer, M.; Bogdal, C.; Hung, H.; Salamova, A.; Venier, M.; Katsoyiannis, A.; Hites, R.A.; Hungerbuhler, K.; Fiedler, H. Ten years after entry into force of the Stockholm Convention: What do air monitoring data tell about its effectiveness? Environ. Pollut. 2016, 217, 149-158. [CrossRef]

22. Lin, T.; Li, J.; Xu, Y.; Liu, X.; Luo, C.; Cheng, H.; Chen, Y.; Zhang, G. Organochlorine pesticides in seawater and the surrounding atmosphere of the marginal seas of China: Spatial distribution, sources and air-water exchange. Sci. Total Environ. 2012, 435-436, 244-252. [CrossRef] [PubMed]

23. Zhang, Z.; Pei, N.; Sun, Y.; Li, J.; Li, X.; Yu, S.; Xu, X.; Hu, Y.; Mai, B. Halogenated organic pollutants in sediments and organisms from mangrove wetlands of the Jiulong River Estuary, South China. Environ. Res. 2019, 171, 145-152. [CrossRef] [PubMed]

24. Bayen, S. Occurrence, bioavailability and toxic effects of trace metals and organic contaminants in mangrove ecosystems: A review. Environ. Int. 2012, 48, 84-101. [CrossRef] [PubMed]

25. Liu, J.; Qi, S.; Yao, J.; Yang, D.; Xing, X.; Liu, H.; Qu, C. Contamination characteristics of organochlorine pesticides in multimatrix sampling of the Hanjiang River Basin, southeast China. Chemosphere 2016, 163, 35-43. [CrossRef] [PubMed]

26. Zhao, G.; Xu, Y.; Li, W.; Han, G.; Ling, B. PCBs and OCPs in human milk and selected foods from Luqiao and Pingqiao in Zhejiang, China. Sci. Total Environ. 2007, 378, 281-292. [CrossRef] [PubMed] 
27. Ali, U.; Syed, J.H.; Malik, R.N.; Katsoyiannis, A.; Li, J.; Zhang, G.; Jones, K.C. Organochlorine pesticides (OCPs) in South Asian region: A review. Sci. Total Environ. 2014, 476-477, 705-717. [CrossRef]

28. Weber, J.; Halsall, C.J.; Muir, D.; Teixeira, C.; Small, J.; Solomon, K.; Hermanson, M.; Hung, H.; Bidleman, T. Endosulfan, a global pesticide: A review of its fate in the environment and occurrence in the Arctic. Sci. Total Environ. 2010, 408, 2966-2984. [CrossRef]

29. Stemmler, I.; Lammel, G. Cycling of DDT in the global environment 1950-2002: World ocean returns the pollutant. Geophys. Res. Lett. 2009, 36, L24602. [CrossRef]

30. Feng, J.; Huang, Q.; Qi, F.; Guo, J.; Lin, G. Utilization of exotic Spartina alterniflora by fish community in the mangrove ecosystem of Zhangjiang Estuary: Evidence from stable isotope analyses. Biol. Invasions 2015, 17, 2113-2121. [CrossRef]

31. Li, M.S.; Mao, L.J.; Shen, W.J.; Liu, S.Q.; Wei, A.S. Change and fragmentation trends of Zhanjiang mangrove forests in southern China using multi-temporal Landsat imagery (1977-2010). Estuar. Coast. Shelf Sci. 2013, 130, 111-120. [CrossRef]

32. Zhang, R.; Yan, C.; Liu, J. Effect of Mangroves on the Horizontal and Vertical Distributions of Rare Earth Elements in Sediments of the Zhangjiang Estuary in Fujian Province, Southeastern China. J. Coast. Res. 2013, 29, 1341-1350. [CrossRef]

33. Xue, B.; Yan, C.; Lu, H.; Bai, Y. Mangrove-Derived Organic Carbon in Sediment from Zhangjiang Estuary (China) Mangrove Wetland. J. Coast. Res. 2009, 254, 949-956. [CrossRef]

34. Chai, M.; Ding, H.; Shen, X.; Li, R. Contamination and ecological risk of polybrominated diphenyl ethers (PBDEs) in surface sediments of mangrove wetlands: A nationwide study in China. Environ. Pollut. 2019, 249, 992-1001. [CrossRef] [PubMed]

35. Shi, C.; Ding, H.; Zan, Q.; Li, R. Spatial variation and ecological risk assessment of heavy metals in mangrove sediments across China. Mar. Pollut. Bull. 2019, 143, 115-124. [CrossRef]

36. Li, Y.F.; Cai, D.J.; Shan, Z.J.; Zhu, Z.L. Gridded Usage Inventories of Technical Hexachlorocyclohexane and Lindane for China with $1 / 6^{\circ}$ Latitude by $1 / 4^{\circ}$ Longitude Resolution. Arch. Environ. Contam. Toxicol. 2001, 41, 261-266. [CrossRef] [PubMed]

37. Wang, Q.; Zhao, L.; Fang, X.; Xu, J.; Li, Y.; Shi, Y.; Hu, J. Gridded usage inventories of chlordane in China. Front. Environ. Sci. Eng. 2013, 7, 10-18. [CrossRef]

38. Burton, G.A., Jr. Sediment quality criteria in use around the world. Limnology 2002, 3, 65-76. [CrossRef]

39. Long, E.R.; Macdonald, D.D.; Smith, S.L.; Calder, F.D. Incidence of adverse biological effects within ranges of chemical concentrations in marine and estuarine sediments. Environ. Manag. 1995, 19, 81-97. [CrossRef]

40. Macdonald, D.D.; Ingersoll, C.G.; Berger, T.A. Development and evaluation of consensus-based sediment quality guidelines for freshwater ecosystems. Arch. Environ. Contam. Toxicol. 2000, 39, 20-31. [CrossRef]

41. Buchman, M.F. NOAA Screening Quick Reference Tables, NOAA HAZMAT Report 97-2; 0269-7491; Hazardous Materials Response and Assessment Division, National Oceanic and Atmospheric Administration: Seattle, WA, USA, 1999.

42. CSBTS. Marine Sediment Quality (GB/T 18668-2002); China Environmental Science Press: Beijing, China, 2002.

43. Willett, K.L.; Ulrich, E.M.; Hites, R.A. Differential toxicity and environmental fates of hexachlorocyclohexane isomers. Environ. Sci. Technol. 1998, 32, 2197-2207. [CrossRef]

44. Iwata, H.; Tanabe, S.; Sakai, N.; Tatsukawa, R. Distribution of persistent organochlorines in the oceanic air and surface seawater and the role of ocean on their global transport and fate. Environ. Sci. Technol. 1993, 27, 1080-1098. [CrossRef]

45. Wu, Y.; Wang, X.; Li, Y.; Ya, M.; Luo, H.; Hong, H. Polybrominated diphenyl ethers, organochlorine pesticides, and polycyclic aromatic hydrocarbons in water from the Jiulong River Estuary, China: Levels, distributions, influencing factors, and risk assessment. Environ. Sci. Pollut. Res. 2017, 24, 8933-8945. [CrossRef] [PubMed]

46. Yu, H.-Y.; Li, F.-B.; Yu, W.-M.; Li, Y.-T.; Yang, G.-Y.; Zhou, S.-G.; Zhang, T.-B.; Gao, Y.-X.; Wan, H.-F. Assessment of organochlorine pesticide contamination in relation to soil properties in the Pearl River Delta, China. Sci. Total Environ. 2013, 447, 160-168. [CrossRef] [PubMed]

47. Garmouma, M.; Poissant, L. Occurrence, temperature and seasonal trends of $\alpha$-and $\gamma$-HCH in air (Québec, Canada). Atmos. Environ. 2004, 38, 369-382. [CrossRef]

48. Walker, K.; Vallero, D.A.; Lewis, R.G. Factors influencing the distribution of lindane and other hexachlorocyclohexanes in the environment. Environ. Sci. Technol. 1999, 33, 4373-4378. [CrossRef] 
49. Sun, D.; Wei, Y.; Li, H.; Yi, X.; You, J. Insecticides in sediment cores from a rural and a suburban area in South China: A reflection of shift in application patterns. Sci. Total Environ. 2016, 568, 11-18. [CrossRef]

50. Yang, D.; Qi, S.-H.; Zhang, J.-Q.; Tan, L.-Z.; Zhang, J.-P.; Zhang, Y.; Xu, F.; Xing, X.-L.; Hu, Y.; Chen, W.; et al. Residues of Organochlorine Pesticides (OCPs) in Agricultural Soils of Zhangzhou City, China. Pedosphere 2012, 22, 178-189. [CrossRef]

51. Hitch, R.K.; Day, H.R. Unusual persistence of DDT in some western USA soils. Bull. Environ. Contam. Toxicol. 1992, 48, 259-264. [CrossRef]

52. Doong, R.-A.; Peng, C.-K.; Sun, Y.-C.; Liao, P.-L. Composition and distribution of organochlorine pesticide residues in surface sediments from the Wu-Shi River estuary, Taiwan. Mar. Pollut. Bull. 2002, 45, 246-253. [CrossRef]

53. Doong, R.-A.; Sun, Y.-C.; Liao, P.-L.; Peng, C.-K.; Wu, S.-C. Distribution and fate of organochlorine pesticide residues in sediments from the selected rivers in Taiwan. Chemosphere 2002, 48, 237-246. [CrossRef]

54. Qiu, X.; Zhu, T. Using the o, $\mathrm{p}^{\prime}$-DDT/p, $\mathrm{p}^{\prime}$-DDT ratio to identify DDT sources in China. Chemosphere 2010, 81, 1033-1038. [CrossRef] [PubMed]

55. Qiu, X.; Zhu, T.; Yao, B.; Hu, J.; Hu, S. Contribution of dicofol to the current DDT pollution in China. Environ. Sci. Technol. 2005, 39, 4385-4390. [CrossRef] [PubMed]

56. Yu, H.-Y.; Shen, R.-L.; Liang, Y.; Cheng, H.; Zeng, E.Y. Inputs of antifouling paint-derived dichlorodiphenyltrichloroethanes (DDTs) to a typical mariculture zone (South China): Potential impact on aquafarming environment. Environ. Pollut. 2011, 159, 3700-3705. [CrossRef] [PubMed]

57. Jia, H.; Li, Y.-F.; Wang, D.; Cai, D.; Yang, M.; Ma, J.; Hu, J. Endosulfan in China 1-gridded usage inventories. Environ. Sci. Pollut. Res. 2009, 16, 295-301. [CrossRef] [PubMed]

58. Wang, B.; Huang, J.; Lu, Y.; Arai, S.; Iino, F.; Morita, M.; Yu, G. The pollution and ecological risk of endosulfan in soil of Huai' an city, China. Environ. Monit. Assess. 2012, 184, 7093-7101. [CrossRef] [PubMed]

59. Zheng, G.J.; Lam, M.H.W.; Lam, P.K.S.; Richardson, B.J.; Man, B.K.W.; Li, A.M.Y. Concentrations of Persistent Organic Pollutants in Surface Sediments of the Mudflat and Mangroves at Mai Po Marshes Nature Reserve, Hong Kong. Mar. Pollut. Bull. 2000, 40, 1210-1214. [CrossRef]

60. Wu, Y.; Wang, X.; Ya, M.; Li, Y.; Hong, H. Distributions of organochlorine compounds in sediments from Jiulong River Estuary and adjacent Western Taiwan Strait: Implications of transport, sources and inventories. Environ. Pollut. 2016, 219, 519-527. [CrossRef]

61. Tang, Y.; Fang, Z.; Yu, S. Heavy metals, polycyclic aromatic hydrocarbons and organochlorine pesticides in the surface sediments of mangrove swamps from coastal sites along the Leizhou Peninsula, South China. Acta Oceanol. Sin. 2008, 27, 42-53.

62. Qiu, Y.-W.; Zhang, G.; Guo, L.-L.; Cheng, H.-R.; Wang, W.-X.; Li, X.-D.; Wai, O.W. Current status and historical trends of organochlorine pesticides in the ecosystem of Deep Bay, South China. Estuar. Coast. Shelf Sci. 2009, 85, 265-272. [CrossRef]

63. Liu, H.; Qi, S.; Su, Q.; Fu, Y.; Wang, J.; Mu, Q. Compositive characteristics of organochlorine pesticides in surface sediments of Dongzhai Harbor, Hainan Island. China Environ. Sci. 2007, 27, 97-101. (In Chinese) [CrossRef]

64. Wu, Q.; Leung, J.Y.; Yuan, X.; Huang, X.; Li, H.; Huang, Z.; Li, Y. Biological risk, source and pollution history of organochlorine pesticides (OCPs) in the sediment in Nansha mangrove, South China. Mar. Pollut. Bull. 2015, 96, 57-64. [CrossRef] [PubMed]

65. Ding, Y.; Huang, H.; Li, H.; Luo, J.; Zheng, H.; Sun, Y.; Yang, D.; Zhang, Y.; Qi, S. Residues of Organochlorine Pesticides (OCPs) in Water and Sediments from Nansha Mangrove Wetland. Environ. Sci. 2017, 38, 1431-1441. (In Chinese) [CrossRef]

66. Kaiser, D.; Schulz-Bull, D.E.; Waniek, J.J. Profiles and inventories of organic pollutants in sediments from the central Beibu Gulf and its coastal mangroves. Chemosphere 2016, 153, 39-47. [CrossRef]

67. Qu, C.; Qi, S.; Yang, D.; Huang, H.; Zhang, J.; Chen, W.; Yohannes, H.K.; Sandy, E.H.; Yang, J.; Xing, X. Risk assessment and influence factors of organochlorine pesticides (OCPs) in agricultural soils of the hill region: A case study from Ningde, southeast China. J. Geochem. Explor. 2015, 149, 43-51. [CrossRef]

68. Zhao, Z.; Jiang, Y.; Li, Q.; Cai, Y.; Yin, H.; Zhang, L.; Zhang, J. Spatial correlation analysis of polycyclic aromatic hydrocarbons (PAHs) and organochlorine pesticides (OCPs) in sediments between Taihu Lake and its tributary rivers. Ecotoxicol. Environ. Saf. 2017, 142, 117-128. [CrossRef] 
69. Bao, L.-J.; Maruya, K.A.; Snyder, S.A.; Zeng, E.Y. China's water pollution by persistent organic pollutants. Environ. Pollut. 2012, 163, 100-108. [CrossRef]

70. Li, H.; Zeng, E.Y.; You, J. Mitigating pesticide pollution in China requires law enforcement, farmer training, and technological innovation. Environ. Toxicol. Chem. 2014, 33, 963-971. [CrossRef]

71. Grung, M.; Lin, Y.; Zhang, H.; Steen, A.O.; Huang, J.; Zhang, G.; Larssen, T. Pesticide levels and environmental risk in aquatic environments in China-A review. Environ. Int. 2015, 81, 87-97. [CrossRef]

72. Wang, Y.; Wang, Y.; Huo, X.; Zhu, Y. Why some restricted pesticides are still chosen by some farmers in China? Empirical evidence from a survey of vegetable and apple growers. Food Control. 2015, 51, 417-424. [CrossRef]

73. Zeng, F.; Yang, D.; Xing, X.; Qi, S. Evaluation of Bayesian approaches to identify DDT source contributions to soils in Southeast China. Chemosphere 2017, 176, 32-38. [CrossRef]

74. Huang, J.; Yang, J.; Rozelle, S. China's agriculture: Drivers of change and implications for China and the rest of world. Agric. Econ. 2010, 41, 47-55. [CrossRef]

75. Zhao, W.; Shen, H. A statistical analysis of China's fisheries in the 12th five-year period. Aquac. Fish. 2016, 1, 41-49. [CrossRef]

76. Asrat, S.; Yesuf, M.; Carlsson, F.; Wale, E. Farmers' preferences for crop variety traits: Lessons for on-farm conservation and technology adoption. Ecol. Econ. 2010, 69, 2394-2401. [CrossRef]

77. Chen, Y.; Li, X.; Tian, Y.; Tan, M. Structural change of agricultural land use intensity and its regional disparity in China. J. Geogr. Sci. 2009, 19, 545-556. [CrossRef]

78. Shen, L.; Xia, B.; Dai, X. Residues of persistent organic pollutants in frequently-consumed vegetables and assessment of human health risk based on consumption of vegetables in Huizhou, South China. Chemosphere 2013, 93, 2254-2263. [CrossRef]

79. Gong, X.; Qi, S.; Wang, Y.; Julia, E.B.; Lv, C. Historical contamination and sources of organochlorine pesticides in sediment cores from Quanzhou Bay, Southeast China. Mar. Pollut. Bull. 2007, 54, 1434-1440. [CrossRef]

(C) 2020 by the authors. Licensee MDPI, Basel, Switzerland. This article is an open access article distributed under the terms and conditions of the Creative Commons Attribution (CC BY) license (http://creativecommons.org/licenses/by/4.0/). 